\title{
PENGUATAN KAPASITAS PEMERINTAH DESA DUNGGALA KECAMATAN TIBAWA MENUJU DESA BERBASIS INFORMATION AND COMMUNICATION TECHNOLOGY
}

\author{
Amirudin Yunus Dako ${ }^{1 *}$, Jumiati Ilham ${ }^{1}$ \\ ${ }^{1}$ Jurusan Teknik Elektro, Fakultas Teknik, Universitas Negeri Gorontalo, Gorontalo, Indonesia \\ *Penulis Korespodensi : amirudin.dako@ung.ac.id
}

\begin{abstract}
Abstrak
Desa Dunggala terletak di kecamatan Tibawa Kabupaten Gorontalo, memiliki tipologi persawahan dengan klasifikasi desa swakarya pada kategori lanjut. Observasi awal yang telah dilakukan mendapatkan bahwa desa ini belum memiliki dokumen profil desa, monografi desa, peta desa, website desa serta data yang ada tidak menyatu dalam dokumen yang utuh. Pengelolaan data desa sudah dilakukan dengan komputer tetapi masih terpisah-pisah dan menggunakan aplikasi yang berbeda-beda dan tidak sesuai peruntukannya. Program pengabdian ini ditujukan untuk melakukan penguatan kapasitas pemerintah desa dalam mewujudkan desa Dunggala sebagai desa berbasis information and communication technology, melalui serangkaian kegiatan penguatan kapasitas untuk memetakan aset dan sumber daya desa serta analisis kondisi desa untuk dituangkan dalam dokumen profil desa yang komprehensif dan lengkap sesuai ketentuan yang berlaku, dikelola secara berkelanjutan dalam sistem informasi desa berbentuk website sebagai sarana penyampaian informasi yang terakses secara mudah dan global. Setelah melalui serangkaian pelatihan dan pendampingan, pada akhir program pengabdian aparat pemerintah desa telah dapat mengelola data profil desa di dalam sebuah website desa berbasis sistem informasi geografis yang terakses global dan dikelola secara berkelanjutan, yang memuat peta desa, data kependudukan, profil desa, monografi desa, desa dalam angka, dilengkapi modul surat menyurat otomatis dan papan informasi digital.
\end{abstract}

Kata kunci: penguatan kapasitas, information and communication technology, desa Dunggala

\begin{abstract}
Dunggala Village, located in the Tibawa sub-district of Gorontalo Regency, has a typology of paddy fields with village classification in the advanced category. Preliminary observations have been made to find that this village does not yet have village profile documents, village monographs, village maps, village websites and existing data are not integrated in the full document. Village data management has been carried out with a computer but is still fragmented and uses different applications that are not suitable for their purpose. This dedication program is intended to strengthen the capacity of the village government in realizing Dunggala village as a village based on information and communication technology, through a series of capacity building activities to map village assets and resources and analysis of village conditions to be set out in a comprehensive and complete village profile document in accordance with the provisions prevailing, sustainably managed in a village information system in the form of a website as a means of delivering information that is accessed easily and globally. After going through a series of training and mentoring, at the end of the service program the village government officials have been able to manage village profile data on a village website based on a geographic information system that is globally accessed and sustainably managed, containing village maps, population data, village profiles, village monographs, villages in numbers, equipped with automatic correspondence modules and digital information boards.
\end{abstract}

Keywords: capacity building, information and communication technology, Dunggala village

\section{PENDAHULUAN}

1.1 Latar Belakang

Desa Dunggala terletak di kecamatan Tibawa Kabupaten Gorontalo, memiliki luas $4 \mathrm{~km} 2$, dengan jumlah penduduk sebanyak 1805 jiwa, 526 Kepala Keluarga (KK) terdiri atas 893 laki-laki dan 912 perempuan (BPS Kabupaten Gorontalo, 2018). Desa ini memiliki tipologi persawahan dengan klasifikasi swakarya pada kategori Lanjut. Mata 
pencaharian utama masyarakat adalah petani (353 orang), buruh tani (32 orang), Pegawai Negeri Sipil (63 orang) dan selebihnya adalah peternak, TNI/Polri, pengusaha dan pedagang keliling (Departemen Dalam Negeri Republik Indonesia, 2018).

Observasi awal yang telah dilakukan bersama aparat desa, yang ditujukan untuk mendapatkan gambaran awal kondisi desa serta mengamati proses pengelolaan dan operasional pemerintahan desa, mendapati bahwa desa ini belum memiliki dokumen profil desa yang lengkap sesuai ketetapan (Pemerintah Indonesia, 2007), belum memiliki monografi desa (Pemerintah Indonesia, 2012), peta desa, website desa serta data yang ada tidak menyatu dalam dokumen profil desa yang utuh. Data monografi desa yang terpampang di kantor desa misalnya, hanya memuat format isian yang kosong dan tidak berisi data sama sekali. Lebih lanjut, pengelolaan data desa sudah dilakukan dengan komputer tetapi masih terpisah-pisah dan menggunakan aplikasi yang berbeda-beda dan tidak sesuai peruntukannya.

Hasil penelusuran internet mendapati bahwa antara sumber data yang satu dengan lainnya berbeda meski dalam tahun yang sama. Jumlah KK misalnya, untuk tahun pelaporan 2017, dokumen kecamatan Tibawa dalam angka halaman 29 mencantumkan bahwa jumlah KK sebanyak 526, sedangkan pada data pokok desa Dunggala pada laman web sistem informasi desa dan kelurahan dikelola oleh Kementrian Dalam Negeri RI Dirjen Pemberdayaan Masyarakat menuliskan sebanyak 523 KK.

Wawancara lebih lanjut bersama pemerintah desa menemukan beberapa masalah:

1. Sumber daya manusia (SDM) penyelenggara pemerintahan desa belum memiliki kapasitas maupun kompetensi yang cukup dalam pengolahan dan analisis data serta belum sepenuhnya menguasai teknik pengolahan data dengan bantuan komputer. Aplikasi yang paling banyak digunakan hanyalah pengolah kata (Microsoft Word). Jika ada proses perhitungan transaksional atau yang melibatkan kalkulasi numerik, maka mereka hanya menggunakan kalkulator dan menuliskannya secara manual.

2. belum ada kegiatan bimbingan maupun pendampingan penyelenggara pemerintahan dalam menyusun profil desa,

3. Data yang tersedia terpisah-pisah dan tidak terintegrasi dalam dokumen yang komprehensif baik dalam bentuk profil desa, monografi desa maupun dokumen sejenis lainnya,

4. Banyaknya data yang harus digali, diperbaharui dan diinput ke dalam format dokumen standar profil desa sangat membutuhkan tenaga, waktu dan biaya yang tidak sedikit. Kurangnya data untuk penyusunan profil desa yang detail, valid dan akurat menyulitkan penyelenggara pemerintahan di desa menentukan kebijakan pembangunan desa serta perencanaan desa. Beberapa data hanya diestimasi besarannya dan tidak dilakukan pengukuran, misalnya peta desa hanya diukur dengan speedometer yang ada pada sepeda motor,

5. Sistem pengelolaan data masih manual dan hanya mengandalkan aplikasi yang belum didesain secara khusus untuk pengelolaan data desa yang terpadu. Aplikasi yang dipakai belum mampu memproses data secara cepat, sehingga menghambat proses pelayanan di desa.

6. Belum ada sistem informasi desa (website) yang bisa diakses secara mudah oleh masyarakat Desa dan semua pemangku kepentingan.

Dalam dokumen Rencana Pembangunan Jangka Menengah Desa (RPJMDes) yang diperlihatkan oleh kepala desa, dalam beberapa tahun kedepan selama periode pemerintahan berjalan, arah pengembangan desa akan diproyeksikan sebagai desa berbasis ICT (Information and Communication Technology) sebagai salah satu program prioritas disamping peningkatan usaha pertanian dan peternakan serta beberapa program peningkatan ekonomi masyarakat lainnya (Pemerintah Desa Dunggala, 2017).

Pencapaian tujuan dalam kerangka mewujudkan adanya desa berbasis ICT saat ini sedang digagas dan dipersiapkan, antara lain dengan penyediaan sarana internet di desa berupa hotspot di kantor desa, yang teralokasi pada tahun anggaran 2017/2018. Sayangnya untuk sarana penyampaian informasi desa berupa website belum tersedia, sebagaimana diamanatkan oleh undangundang (Pemerintah Indonesia, 2014). Kendala lainnya sebagaimana diungkap sebelumnya adalah lemahnya kapasitas SDM dalam menyediakan konten sistem informasi desa yang memuat data profil desa secara lengkap, detil dan terbaharui.

Pemerintah desa menyadari bahwa ketersediaan, kebaruan dan keberlanjutan pengelolaan data profil desa sangat berperan penting dalam penyelenggaraan pemerintahan, penentuan kebijakan, proses perencanaan pembangunan desa khususnya dalam penyusunan RPJMDes dan secara khusus merupakan titik tolak upaya mewujudkan desa berbasis ICT yang berbasis pada keterbukaan informasi yang valid, terbaharui dan mudah diakses. Terkait dengan hal dimaksud, pemerintah desa telah menetapkan bahwa langkah awal mewujudkan desa berbasis ICT adalah membangun infrastruktur sarana penyampaian informasi yang terbuka dan mudah diakses dalam bentuk sistem informasi desa berbasis web (website), yang memuat data profil desa yang terbaharui serta dapat dikelola secara berkelanjutan, dan selanjutnya kepala desa mengharapkan adanya dukungan dari Universitas Negeri Gorontalo (UNG) dalam merintis langkah awal mewujudkan tujuan desa Dunggala sebagai desa berbasis ICT. 


\subsection{Penyelesaian Masalah}

Secara umum solusi permasalahan yang diusulkan dalam program pengabdian ini adalah melakukan penguatan kapasitas dalam bentuk pemberdayaan aparat penyelenggara pemerintahan desa dalam merintis langkah awal pencapaian tujuan mewujudkan desa Dunggala sebagai desa berbasis ICT, melalui serangkaian kegiatan pendampingan dan pelatihan yang ditujukan untuk memetakan aset dan sumber daya desa serta melakukan analisis kondisi desa untuk selanjutnya dituangkan dalam dokumen profil desa yang komprehensif dan lengkap sesuai ketentuan yang berlaku, dan dikelola lebih lanjut dalam sistem informasi desa berbasis web sebagai sarana penyampaian informasi desa yang terakses secara mudah dan global serta dikelola secara berkelanjutan.

Untuk mengoptimalkan ketercapaian tujuan kegiatan, tim program pengabdian akan bekerjasama dengan mitra eksternal maupun internal kampus yang berasal dari organisasi nirlaba maupun kelompok studi mahasiswa yang memiliki kompetensi, kapasitas dan berpengalaman memfasilitasi kegiatan program pengabdian maupun kegiatan serupa pada tahun-tahun sebelumnya. Mitra dimaksud adalah Japesda Gorontalo, sebuah organisasi non profit yang berpengalaman dalam memfasilitasi proses pemberdayaan masyarakat dan kelompok studi mahasiswa pecinta alam Alaska yang ada di fakultas Teknik Universitas Negeri Gorontalo.

\section{BAHAN DAN METODE}

\subsection{Lokasi kegiatan}

Program pengabdian ini dilaksanakan di Desa Dunggala Kecamatan Tibawa Kabupaten Gorontalo Provinsi Gorontalo, dengan waktu efektif di lapangan kurang lebih 3 bulan selama bulan Juni - Agustus 2019.

\subsection{Kelompok Sasaran}

Kelompok sasaran program adalah aparat pemerintah desa beserta lembaga-lembaga yang ada di desa, antara lain karang Taruna, pengelola badan usaha milik desa (BUMDES), kader PKK/dasawisma, Badan Permusyawaratan Desa (BPD), Lembaga Pemberdayaan Masyarakat (LPM), Kelompok Wanita Tani Tinelo, Tenaga Hansip, serta kelompok masyarakat lainnya.

\subsection{Perencanaan program}

Program pengabdian ini dikemas dalam bentuk Kuliah Kerja Nyata Pembelajaran dan Pemberdayaan Masyarakat (KKN PPM). Target umum pelaksanaan KKN PPM ini adalah menguatnya kapasitas pengetahuan dan keterampilan aparat penyelenggara pemerintahan desa serta terkumpulnya data dan informasi desa sebanyak mungkin, diolah, dianalisis dan disusun dalam dokumen resmi yang selanjutnya disajikan dalam sistem informasi desa, dan menjadi langkah awal mewujudkan desa berbasis ICT. Tahapan kegiatan KKN PPM dilukiskan pada bagan alir berikut.

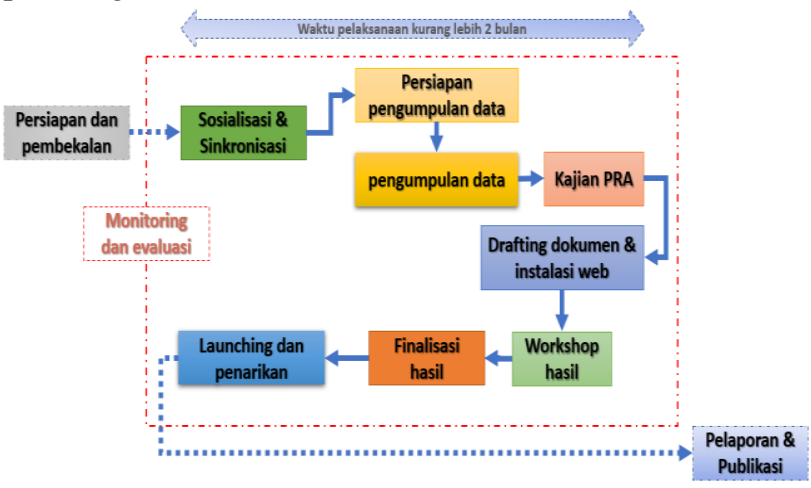

Gambar 1. Bagan alir pelaksaanan program.

\subsection{Metode dan Teknologi yang Diterapkan 2.4.1 Metode}

KKN PPM direncanakan akan melakukan kegiatan terstruktur untuk menjawab permasalahan yang ada, dimulai dari sosialisasi dan sinkronisasi program, analisis kondisi eksisting desa, perumusan rencana kegiatan bersama, penyiapan instrument pengumpulan data, penyiapan kelompok kerja, pelatihan-pelatihan, penguatan kapasitas penyelenggara pemerintahan di desa, pelaksanaan pengumpulan data, pengelolaan data serta publikasi data dalam bentuk dokumen profil desa, monografi desa serta sistem informasi berbasis web untuk pengelolaan data desa yang optimal terbantu komputer.

Keseluruhan kegiatan KKN PPM akan dilakukan bersama masyarakat, aparat desa termasuk kepala desa, PKK, Dasa wisma, karang taruna sebagai mitra desa bersama mitra lainnya, menggunakan metode Participatory Rural Appraisal (PRA/kajian perdesaan Partisipatif) dengan mempertimbangkan aspek gender dan difokuskan pada upaya untuk meningkatkan partisipasi masyarakat dalam setiap pelaksanaan kegiatan yang bertujuan untuk merintis langkah awal pencapaian tujuan mewujudkan desa Dunggala sebagai desa berbasis ICT melalui serangkaian kegiatan pembaruan dan pengelolaan data profil desa secara berkelanjutan dan kemudian disajikan dalam sistem informasi desa berbentuk website sebagai sarana penyampaian informasi yang mudah diakses dan tersedia secara daring.

Metode PRA menjadi metode utama dalam pelaksanaan KKN PPM, yang akan digabungkan dengan beberapa metode lainnya dalam satu kegiatan yang terencana, misalnya untuk kegiatan peningkatan kapasitas penyelenggara pemerintahan desa dalam bentuk pelatihan-pelatihan akan disandingkan dengan metode pembelajaran orang dewasa sesuai dengan salah satu prinsip dasar PRA yaitu santai dan informal.

Salah satu metode lain yang akan dikombinasikan dengan metode PRA adalah metode learning by doing yang akan digunakan dalam kegiatan pembuatan dokumen profil 
desa dengan cara bersama-sama penyelenggara pemerintahan desa membuat dokumen profil desa mulai dari awal sampai proses akhir. Penerapan, pendekatan dan teknik PRA yang dikombinasikan dengan metode lainnya dapat memberi peluang yang lebih besar dan lebih terarah untuk melibatkan masyarakat. Gambaran umum masalah, solusi, penerapan metode dan target/indikator luaran dilukiskan secara grafis berikut.

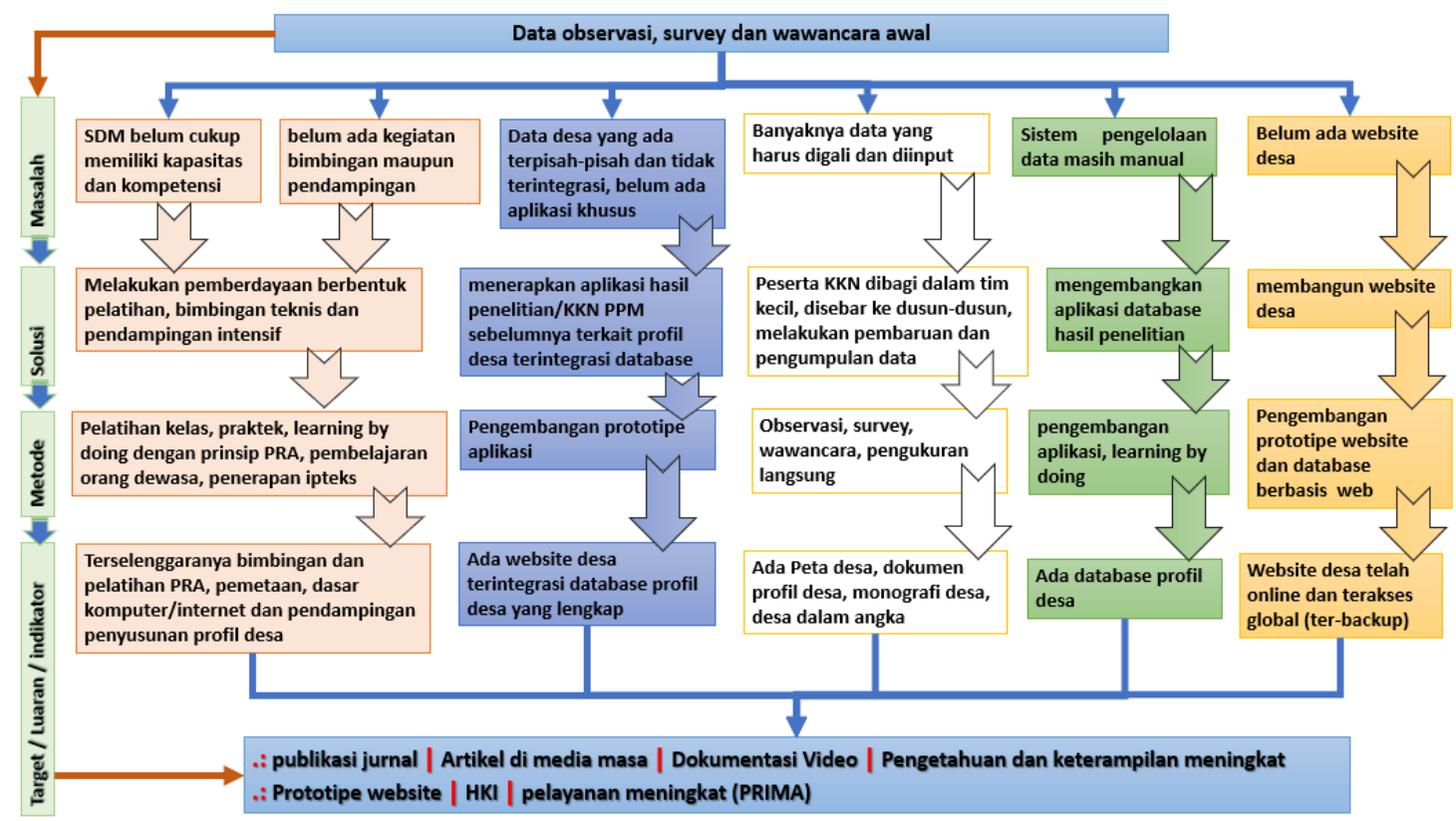

Gambar 2. Gambaran umum masalah, solusi, metode dan target

\subsubsection{Teknologi yang Diterapkan}

Adapun gambaran ilmu pengetahuan dan teknologi (iptek) yang akan diterapkan, lebih lanjut diuraikan sesuai indikator ketercapaian target yang direncanakan sebelumnya yakni

- Penerapan aplikasi komputer untuk pemetaan dan sistem informasi geografis (SIG) menggunakan ARCGIS atau aplikasi pemetaan lainnya, teknik survey dan tracking, pemakaian GPS (global positioning system) untuk menghasilkan Peta Desa Dunggala yang menggambarkan kondisi terkini desa Dunggala dengan format standar lengkap dengan acuan koordinat lokasi,

- Penerapan aplikasi komputer dasar dalam rumpun Microsoft Office (MS Excell, MS Word, MS powerpoint), aplikasi pengolah foto dan video dalam rumpun Adobe studio (Adobe photoshop, Adobe premiere) untuk menghasilkan

- Dokumen Profil desa yang terdiri atas 3 dokumen utama yakni data dasar keluarga, potensi desa dan tingkat perkembangan,

- dokumen Monografi Desa dan desa Dunggala dalam angka,

- dokumentasi kegiatan dan pelaporan kegiatan

- Penerapan aplikasi pemrograman web untuk menghasilkan Prototipe Sistem informasi terpadu berbasis web untuk sajian informasi data profil desa. Aplikasi dimaksud dapat menggunakan HTML (HyperText Markup Language), PHP (pre-Hypertext
Prepocessor), javascript, Xampp [X (empat sistem operasi apapun), Apache, MySQL, PHP dan Perl], MySQL (Structured Query Language), CSS (Cascading Style Sheet) maupun tools web lainnya.

- Penerapan aplikasi berbasis komputer dan pemakaian perangkat teknologi informasi lainnya (dasar komputer, optimasi internet, Raspbery $\mathrm{Pi}$, peraga LCD [liquid crystal display], wifi [wireless fidelity], router, mikrotik, others wireless device) untuk mendukung kegiatan penguatan kapasitas aparat desa dalam kegiatan pelatihan, temu desa, sosialisasi, workshop serta pengelolaan sistem informasi berbasis web secara umum.

\section{HASIL DAN PEMBAHASAN}

Hasil dan luaran yang dicapai diuraikan berturut-turut sesuai dengan tahapan pelaksanaan sebagai berikut:

\subsection{Sosialisasi dan Sinkronisasi Program}

Sosialisasi dilaksanakan dengan tujuan untuk mengenalkan mahasiswa dengan masyarakat, menjelaskan maksud dan tujuan kegiatan serta menjaring sebanyak-banyaknya informasi awal kondisi desa, menemukenali potensi dan permasalahan serta memetakan sumber daya desa yang dapat bersinergi dalam mendukung keberhasilan program.

Untuk tahap awal, kegiatan sosialisasi dilaksanakan sekaligus pada saat penerimaan mahasiswa di desa 
sekaligus perkenalan dengan aparat desa. Bentuk sosialisasi lain dilaksanakan secara non formal dalam kegiatan kemasyarakatan di desa, misalnya ada hajatan pernikahan, syukuran maupun kegiatan keagamaan atau dalam bentuk program Safari jumat yakni ibadah jumat secara bergiliran di seluruh mesjid yang ada di desa. Cara lainnya adalah secara door to door pada saat observasi wilayah desa.

Sinkronisasi program ditujukan untuk mengintegrasikan program KKN PPM dengan agenda kegiatan pemerintah desa sehingga saling menopang dan berkontribusi positif sesuai dengan tujuan atau rencana pembangunan yang ada di desa. Sinkronisasi dilakukan bersamaan dengan tahapan sosialisasi, secara non formal melalui diskusi dengan pemerintah desa atau melakukan pencermatan pada dokumen rencana pembangunan jangka menengah desa (RPJMDes) dengan berfokus ada kegiatan yang sifatnya mendesak dan memungkinkan untuk dapat dilakukan selama periode pelaksanaan program KKN PPM.

Kedua tahapan ini menghasilkan gambaran awal permasalahan yang ada di desa, sumber daya yang tersedia, serta prioritas program dan masalah yang harus segera diselesaikan. Gambaran yang didapat kemudian didiskusikan di tingkat internal tim KKN PPM dan selanjutnya menghasilkan jadwal dan rencana tindak tim KKN PPM yang memuat mekanisme pelaksanaan program inti yang tersinkronisasi dengan agenda kegiatan pemerintah maupun masyarakat desa, serta rumusan program kegiatan inti bersama dan program tambahan.

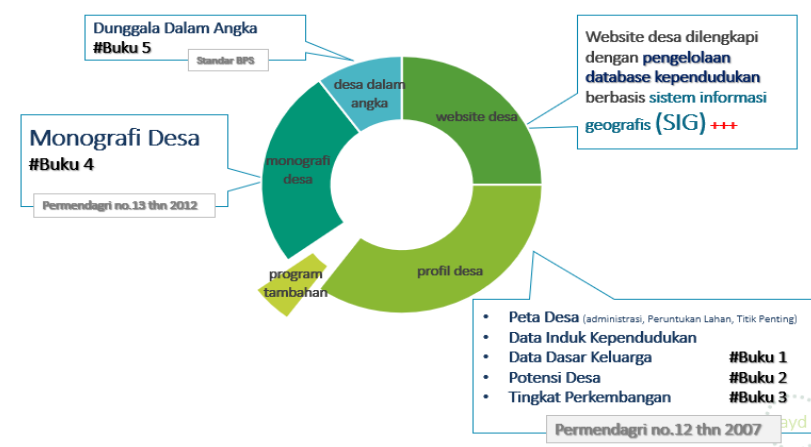

Gambar 3. Program Inti.

Program tambahan yang dirumuskan antara lain

- Perluasan cakupan layanan internet, ditujukan agar fasilitas internet desa dapat dinikmati oleh masyarakat yang lokasi rumahnya jauh dari kantor desa,

- Pembuatan papan informasi digital memakai TV untuk dipasang di loby kantor desa,

- Pembuatan peta tematik tambahan, membuat peta peruntukan lahan secara detail, peta infrastruktur, dan lokasi pejabat desa,
- Penyiapan sarana mitigasi bencana, membuat jalur evakuasi bencana dan menentukan titik kumpul evakuasi serta peta potensi bencana di desa,

- Lomba desa, membuat profil desa naratif,

- Desain layanan administrasi online, menambahkan menu untuk layanan pembuatan surat secara online melalui Whatsapp atau dengan mengisi permohonan pembuatan surat pada laman pengajuan pada website, Optimasi website, menambahkan modul untuk visualisasi data kependudukan dalam bentuk grafik dinamis,

- Pembuatan infografis desa, mendesain baliho untuk menyajikan informasi program pembangunan serta transparansi pengelolaan keuangan desa.

\subsection{Pembuatan Profil Desa}

\subsubsection{Persiapan dan Pembekalan Tim}

Persiapan dilakukan untuk melakukan persiapan tim yang meliputi pembekalan, pembentukan tim, penyiapan jadwal, penyiapan format pengambilan data. Pembekalan dilakukan dengan mengenalkan secara ringkas terkait teknik PRA melalui pelatihan dengan metode non formal dalam kelas bagi mahasiswa.

Selanjutnya tim kemudian dibentuk dan diorganisir sesuai dengan tugas pokok dan fungsi (tupoksi) masing-masing, antara lain tim surveyor, tim pemetaan, tim web, tim analis (excel), tim dokumentasi, tim infografis (photoshop), tim administrasi/training, dan supporting tim.

\subsubsection{Pengambilan Data}

Pengambilan data dilakukan selama kurang lebih 1 minggu di semua dusun bersama dengan kepala dusun dan aparat desa, dengan cara mendatangi rumah penduduk untuk diwawancarai menggunakan format pengambilan data yang telah disiapkan. Jumlah rumah yang disurvey tercatat sebanyak 135 rumah, $536 \mathrm{KK}$ dan 1844 jiwa (data per 8 Agustus 2019). Pada tahap ini pula dilakukan pengambilan data spasial yang ditujukan untuk memperbaharui kembali sketsa peta yang telah dibuat sebelumnya.

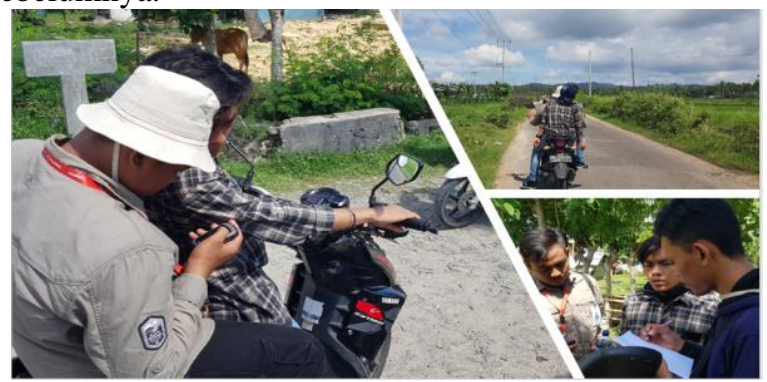

Gambar 4 Proses pengambilan koordinat memakai GPS. 3.2.3 Analisis Data

Analisis data kependudukan dilakukan setelah kegiatan pengambilan data selesai. Kegiatan ini dilaksanakan di posko utama oleh tim yang telah ditunjuk. Data kependudukan yang didapat kemudian diolah dengan aplikasi MS Excell untuk analisis lebih lanjut. Pada 
tahapan ini dilaksanakan pengurutan, pengklasifikasian, triangulasi serta validasi dan koreksi data, dilakukan bersama kepala desa dan aparat desa. Luaran dari tahapan ini kemudian menjadi dasar bagi penyusunan buku profil, monografi desa serta desa dalam angka pada tahapan berikutnya.

\subsubsection{Penyusunan Draft Profil Desa}

Penyusunan draft profil desa dipusatkan di posko induk oleh tim penyusun, berdasarkan input data yang telah diolah dan dianalisis pada proses sebelumnya. Draft profil desa yang dimaksud pada bagian ini adalah draft Dokumen Profil Desa Dunggala yang standar (Pemerintah Indonesia, 2007), ditambah dengan Monografi Desa Dunggala yang sesuai ketentuan (Pemerintah Indonesia, 2012) serta draft desa Dunggala Dalam Angka yang mengacu pada standar publikasi Wilayah Kecamatan Dalam Angka oleh Biro Pusat Statistik.

Penyusunan draft dokumen memakan waktu kurang lebih 1 minggu. Setelah draft dokumen telah disusun, kemudian dilakukan konsultasi publik atau asistensi terhadap kandungan materi yang dimuat dalam semua dokumen dimaksud, dilaksanakan bersama perangkat desa dan perwakilan lembaga yang ada di desa. Kegiatan ini merekomendasikan beberapa perubahan dan koreksi atas temuan data lapangan. Rekomendasi dan koreksi yang diperoleh pada konsultasi publik ini kemudian menjadi rujukan bagi finalisasi dokumen profil desa.

Selanjutnya tim melakukan koreksi draft dokumen berdasarkan masukan yang diterima sebelumnya. Proses koreksi draft dokumen dilakukan bersama oleh aparat desa dan peserta KKN PPM dalam kerangka pendampingan pembuatan profil desa dan merupakan rangkaian kegiatan yang terprogram dalam serial pelatihan yang telah direncanakan. Proses selanjutnya adalah finalisasi dokumen profil desa, dilakukan dengan melengkapi dokumen dengan memasukkan sampul laporan, prakata dan kemudian dilakukan pencetakan dan penjilidan dokumen.

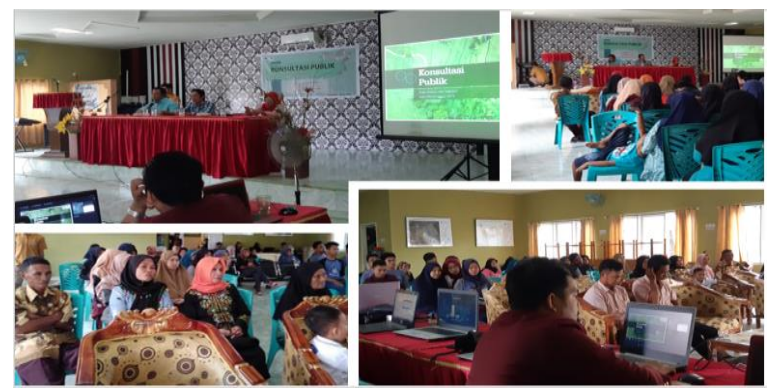

Gambar 5. Konsultasi Publik Materi profil desa.

Finalisasi dokumen profil desa selanjutnya menghasilkan:

1. Buku 1: Profil Desa Dunggala (Data Dasar Keluarga) setebal 43 halaman,
2. Buku 2: Profil Desa Dunggala (Potensi Desa) setebal 50 halaman,

3. Buku 3: profil desa Bongopini (Tingkat Perkembangan) setebal 58 halaman,

4. Buku 4: Monografi desa setebal 21 halaman, dan

5. Buku 5: Dunggala dalam Angka setebal 35 halaman. Lebih lanjut, seluruh dokumen ini akan menjadi sajian informasi website desa pada menu publikasi.

\subsection{Pembuatan Peta}

Pembuatan peta diawali dengan pelatihan pembuatan peta bagi mahasiswa KKN PPM, Aparat desa dan karang taruna yang tergabung dalam tim pemetaan. Materi pelatihan berupa pengenalan GPS, cara mengoperasikan GPS, melakukan digitasi peta dan layout peta. Pelatihan ini memakai metode pembelajaran orang desa, metode learning by doing dan metode penerapan ipteks. Sesi pelatihan terbagi atas dua, yakni sesi kelas berupa pemberian materi serta praktek lapangan.

Data spasial yang diperoleh di lapangan kemudian dilakukan proses digitasi, analisis peta dan layout. Turut dihitung pula penggunaan lahan untuk setiap peruntukan. Proses ini dilaksanakan bersama mitra Alaska dan japesda dalam bentuk tutor sebaya selama kurang lebih 1 minggu, dan menghasilkan luaran berupa 6 peta tematik desa yakni peta dasa wisma, peta wilayah administratif (citra), peta tanggap bencana, peta peruntukan lahan, peta sosial Ekonomi dan peta infrastruktur desa.
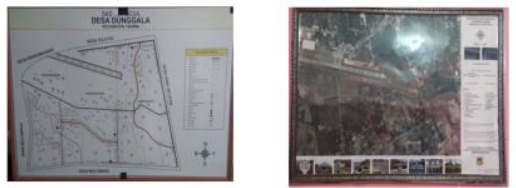

sebelum
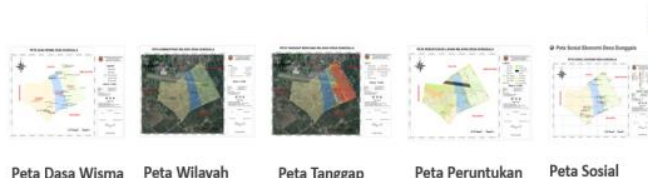

sesudah

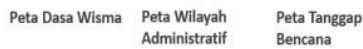

Lahan

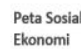

Infrastruktur

Gambar 6. Peta hasil kegiatan pemetaan.

Keseluruhan layout peta menggunakan standar (Badan Informasi dan Geospasial Republik Indonesia, 2016). Selanjutnya perhitungan kuantitas, volume dan luas obyek ruang yang ada di desa dituliskan dalam buku perhitungan pemetaan yang merupakan bagian tak terpisahkan dari kegiatan pembuatan peta. Buku ini juga merupakan sajian informasi website desa yang bisa diunduh dengan gratis.

\subsection{Pembuatan Website}

Pembuatan website dilakukan menggunakan PHPMYSQL yang dapat dipakai secara gratis. Pembuatan website dimaksud adalah sistem informasi berbasis web yang merupakan luaran dari kegiatan penelitian/pengabdian yang telah dilakukan sebelumnya (Dako \& Ilham, 2016), (Ilham \& Dako, 2016) (Dako \& Tolago, 2017). Beberapa pengembangan seperlunya dilakukan untuk memenuhi keinginan user, dalam hal ini 
adalah pemerintah desa Dunggala. Pengembangan dimaksud adalah modifikasi layout, penambahan beberapa fitur dan fungsi serta optimasi website secara keseluruhan.

Website ini telah ditempatkan pada alamat https://dunggala.desa.id, dan telah teruji secara teknis. Penggunaan domain desa.id disesuaikan dengan standar yang dikeluarkan oleh Depkominfo RI. Hasil eksekusi halaman awal dari website desa Dunggala ditunjukkan pada gambar berikut.

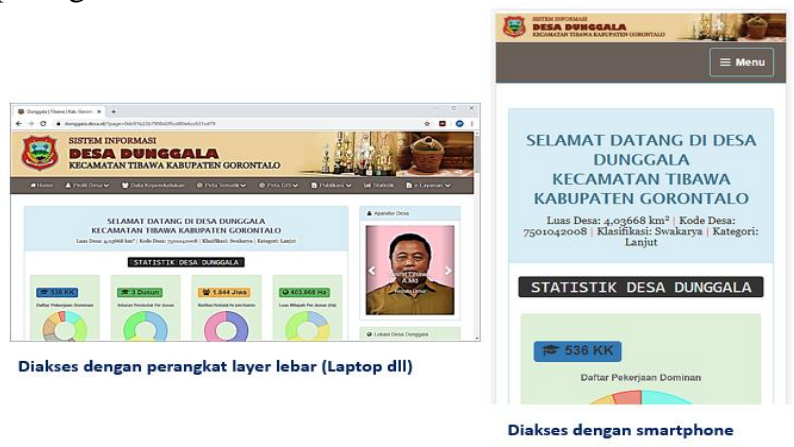

Gambar 7. Cuplikan Halaman Awal Website.

Website ini dilengkapi dirancang dengan teknik responsive web design (RWD) sehingga mampu secara adaptif menyesuaikan tampilan konten yang disajikan mengikuti perangkat pengaksesnya, dan merupakan pengembangan dari hasil kegiatan penelitian dan pengabdian yang dilakukan pada tahun-tahun sebelumnya. Beberapa pengembangan dilakukan unntuk meningkatkan beberapa fungsi dan fitur yang telah ada, antara lain:

- Basis data kependudukan terintegrasi dengan website, dengan peningkatan fitur filtering data dengan opsi kategori yang lebih beragam,

- Penambahan menu untuk visualisasi sebaran data kependudukan, infrastruktur, penerima bantuan, KK Miskin, jabatan di desa, sosial ekonomi berbasis sistem informasi geografis (SIG),

- Visualisasi lokasi kantor desa dan wilayah administrasi desa berbasis SIG (memakai Google Maps),

- Basis data dasawisma yang juga didukung oleh sajian informasi berbasis spasial.

- Fitur layanan administrasi kependudukan untuk menangani permintaan pembuatan surat secara online oleh warga desa

- Fitur kotak saran/aduan digital dan managemen informasi dalam lingkup desa,

- Download file peta resolusi tinggi dan informasi spasial sebaran penduduk,

- Publikasi infografis desa, profil desa, monografi desa, dan desa Dunggala dalam angka.

- Peraga layar lebar papan informasi digital untuk sajian informasi pengumuman, agenda serta presensi aparat desa,
- Penambahan menu statistik / Fitur grafik interaktif untuk sajian informasi kependudukan berbasis pada data terkini yang tersedia dalam basisdata,

- Pengarsipan digital surat masuk dan dokumen penting desa, Pembuatan dan pengarsipan surat keluar terintegrasi dengan basisdata,

- Galery foto dan video yang terintegrasi dengan akun berbagi pakai video secara daring.

Cuplikan hasil eksekusi beberapa fitur dimaksud disajikan pada gambar berikut

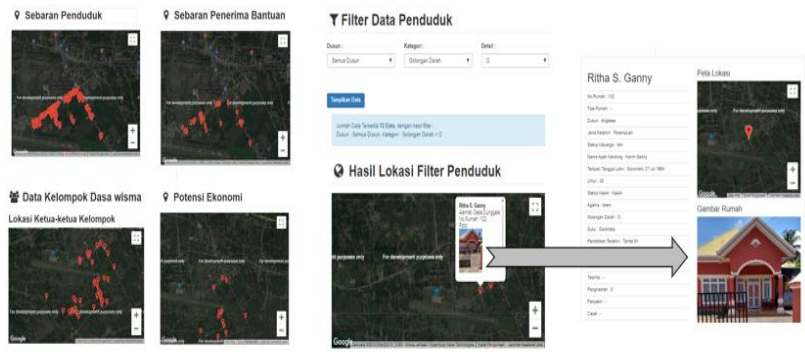

Gambar 8. Cuplikan Sajian Informasi Data Penduduk Dengan Dukungan SIG.
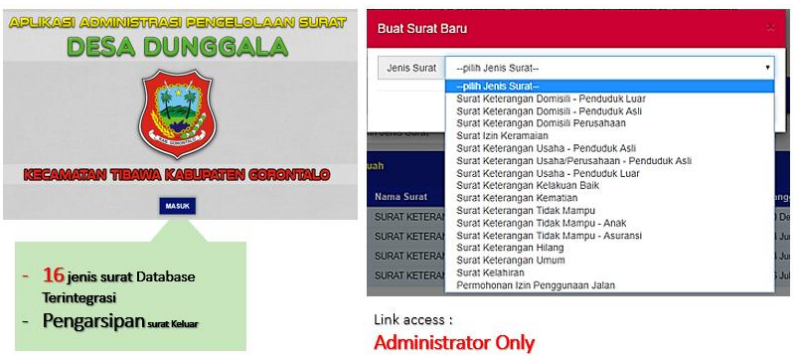

Gambar 9. Aplikasi Surat Menyurat Dengan Dukungan Database Terintegrasi.

Semua hasil kerja KKN PPM dapat diakses pada website ini. Website ini dilengkapi pula dengan buku panduan penggunaan website, baik bagi pengguna umum maupun administrator pengelola website desa, yang secara khusus ditujukan untuk menjadi pegangan dalam pengelolaan website desa dan selanjutnya dapat menjadi dukungan materi bagi pembelajaran dan pelatihan pengelolaan sistem informasi (website) desa pada waktu mendatang. Website ini telah ditetapkan sebagai salah satu pemenang dalam lomba inovasi desa di tingkat Kabupaten Gorontalo.

\subsection{Pelatihan dan Pendampingan}

Kegiatan pelatihan dan pendampingan kelompok sasaran dilakukan secara serial sepanjang pelaksanaan program, meliputi pelatihan Pelatihan Pemetaan / PRA, Pelatihan Pengolahan dan Analisis Data Profil Desa, Pelatihan Dasar Komputer dan internet, Pelatihan Management Database, Pelatihan Management Website dan Penerapan IPTEKS secara umum. Materi Pelatihan ditekankan pada pengenalan aplikasi khususnya MS Excell, MS Word dengan contoh kasus nyata yang dihadapi, misalnya 
mengelola data kependudukan, membuat dokumen profil desa, monografi desa dan desa dalam angka serta pengelolaan konten website desa.

\subsection{Pelaksanaan Program Tambahan}

Program tambahan adalah program diluar program inti, dilaksanakan dalam rangka menunjang program pembangunan desa, bersifat mendesak dan memungkinkan ditangani oleh sumberdaya yang ada dalam tim. Program tambahan dimaksud antara lain:

\subsubsection{Papan Informasi Digital}

Papan informasi digital berupa sebuah peraga informasi berbentuk TV LED berukuran 43" berbasis Raspbery Phi yang dipasang pada loby kantor desa. Sajian informasi yang ada di papan informasi ini dikontrol melalui website desa pada menu pengelolaan papan info digital. Warga desa selanjutnya dapat melihat pengumuman, agenda dan kehadiran aparat desa melalui 'menu papan info' yang ada di website desa, sehingga warga desa yang memiliki kepastian penyelesaian urusan administrasi dengan aparat desa yang memerlukan tatap muka langsung.

\subsubsection{Perluasan Cakupan Layanan Internet Desa}

Ketika tim KKN PPM masuk ke desa Dunggala, layanan internet desa hanya dapat diakses oleh sebagian masyarakat yang berlokasi di sekitar kantor desa, dimana terdapat sebuah access point untuk layanan internet berbasis wireless. Selanjutnya desa memintakan kesediaan tim KKN PPM untuk merealisasikan perluasan cakupan layanan internet desa dengan seluruh pembiayaan ditanggung oleh desa melalui Anggaran Dana Desa yang tersedia.

Perluasan cakupan layanan internet dilakukan dengan membangun 1 (satu) buah menara (tower) yang berfungsi sebagai pemancar dan 3 (tiga) tower lainnya sebagai penerima jaringan internet dan dipasang di titik-titik strategis yang ada di setiap dusun. Tower dibangun dari pipa galvanis ukuran $3,2,1.5$ dan 1 inch, pada pondasi beton cor. Tower pemancar dipasang antena Ubiquiti Bullet M2HP dengan penguat Omni-Directional Hyperlink HG-2415UPRO, sedangkan tower penerima dipasang antena Ubiquiti PowerBeam M2. Di setiap tower penerima kemudian dipasang access point untuk jaringan wifi memakai router Tenda AC6, agar masyarakat sekitar tower dapat menikmati layanan internet desa. Di kantor desa kemudian dipasang switch Dlink 8 port dan Mikrotik rb750gr3, untuk pengaturan lalulintas pemakaian jaringan internet. Disamping itu dilakukan instalasi untuk penambahan Local Area Network (LAN) di kantor desa untuk menghubungkan semua komputer yang dipakai oleh aparat desa.

Pelaksanaan pemasangan tower dan instalasi jaringan internet ini dilakukan pada akhir program. Kondisi terakhir per Juli 2019, cakupan layanan internet desa Dunggala disajikan secara grafis berikut.

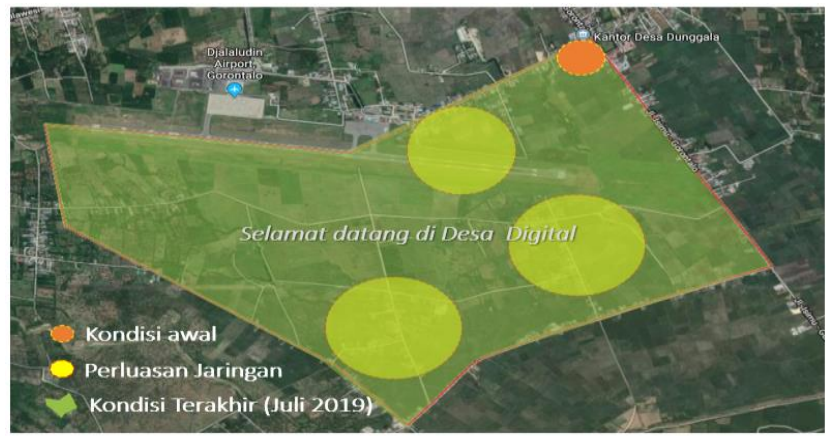

Gambar 10. Kondisi Terakhir Cakupan Layanan Internet Desa Dunggala.

\subsubsection{Penyiapan Sarana Mitigasi Bencana}

Program ini merupakan kelengkapan dari sebuah persyaratan penilaian lomba desa, dimana sebuah desa akan dinilai lebih jika memiliki sarana mitigasi bencana. Tim KKN PPM dalam program ini membuat jalur evakuasi, menentukan titik kumpul dan membuat peta tanggap bencana seperti yang diuraikan pada bagian 5.3 sebelumnya.

\subsection{Launching Website dan Penyerahan Produk KKN PPM}

Launching website dilaksanakan bertepatan dengan kegiatan Bursa Pertukaran Inovasi Desa di kabupaten Gorontalo khususnya cluster Tibawa, yang diselenggarakan oleh seksi Pemerintahan Desa Kecamatan dan diikuti oleh 4 kecamatan di sekitar desa Dunggala. Empat kecamatan dimaksud adalah Kecamatan Tibawa, Kecamatan Pulubala, Kecamatan Bongomeme dan Kecamatan Limboto Barat, dihadiri oleh pimpinan SKPD, Depkominfo Kabupaten, staf ahli bupati, puluhan kepala desa, pendamping inovasi desa, BPD dan seluruh aparat desa dari 4 kecamatan dimaksud.

Website desa Dunggala (https://dunggala.desa.id) menjadi salah satu pemenang dalam lomba inovasi desa di tingkat provinsi Gorontalo, karena setelah dilakukan penelusuran seluruh website desa yang ada di wilayah Republik Indonesia kecuali di provinsi Gorontalo, website desa

Dunggala memiliki beberapa keunggulan antara lain:

- berbasis GIS (Geographic Information System) dan terintegrasi dengan basisdata yang memuat sebaran data penduduk yang detail sampai ke level koordinat lokasi \& foto rumah warga

- memuat Dokumen Profil Desa, Monografi Desa, Desa dalam Angka yang lengkap sesuai standar Permendagri/12/2007, Permendagri/13/2012 dan standar Badan Pusat Statistik, serta bisa diunduh. memuat peta desa sesuai standar (Badan Informasi dan Geospasial Republik Indonesia, 2016), yang detail sampai dengan data luas rumah per petak dan 
luas kebun per petak, lengkap dengan perhitungan luasannya dan bisa diunduh.

- Menampilkan grafik statistik kependuduskan secara dinamis berdasarkan data terbaru yang ada dalam basisdata, khususnya untuk visualisasi grafik piramida penduduk dan grafik lainnya.

Pada kegiatan ini pula, pihak yang mewakili pemerintah Kabupaten dan Provinsi menegaskan bahwa website desa Dunggala selanjutnya dijadikan contoh dan acuan bagi pengembangan website desa lainnya dan meminta kepada pihak UNG agar dapat memfasilitasi keinginan dimaksud.

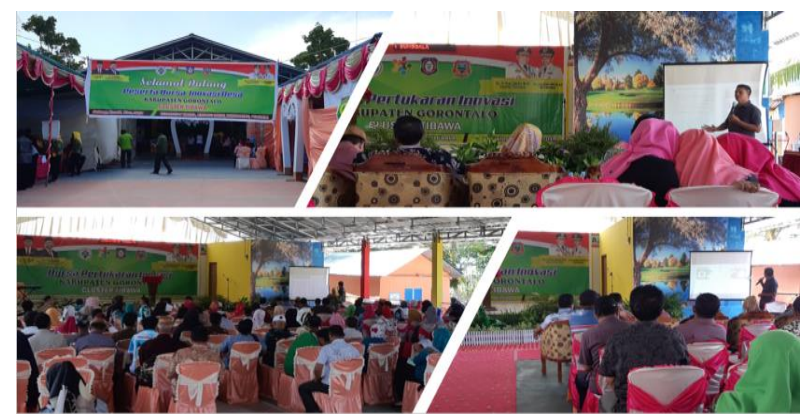

Gambar 11. Launching Website Desa.

Penyerahan produk KKN PPM dilaksakanakan pada saat malam perpisahan dan penarikan peserta. Produk KKN dimaksud adalah seluruh luaran baik cetak maupun digital yang dikemas dalam bentuk buku, CD maupun hak akses terhadap seluruh akun digital yang dibuat oleh Tim KKN PPM khususnya yang terkait dengan website desa.

\subsection{Perolehan HKI}

Website desa Dunggala telah beroleh sertifikat Hak atas Kekayaan Intelektual (HKI) yang diterbitkan oleh Kementrian Hukum dan Hak Asasi Manusia Republik Indonesia dengan judul ciptaan "Sistem Informasi Desa Dunggala Kecamatan Tibawa Kabupaten Gorontalo", jenis ciptaan "Program Komputer" dan nomor pencatatan 000149028.

\subsection{Publikasi}

Publikasi kegiatan KKN PPM telah dilakukan di berbagai media massa dalam berbagai bentuk, antara lain artikel berita pada Kantor Berita ANTARA (Solihin, 2019) dan selanjutnya diberitakan kembali oleh setidaknya 5 biro pemberitaan dalam jaringan kantor berita ANTARA dan satu dari media massa lain yakni infonews.com, data per 15 Agustus 2019. Selain publikasi artikel di media massa, dilakukan pula publikasi berita foto (ANTARAfoto.com, 2019a) (ANTARAfoto.com, 2019b), publikasi di Kompas TV (Kompas TV Gorontalo, 2019) dan Inews TV (iNews Gorontalo, 2019), dan publikasi pada jejaring sosial berbasis video (Bahua, 2019) (Desa Dunggala, 2019b) (Desa Dunggala, 2019a) dan lainnya (dunggala.desa.id, 2019).

\section{KESIMPULAN}

Program KKN PPM di desa Dunggala kecamatan Tibawa Kabupaten Gorontalo, telah menghasilkan

1. Terselenggaranya kegiatan serial pelatihan dan pendampingan untuk aparat desa Dunggala dalam bentuk pelatihan PRA, pelatihan dasar komputer/internet, managemen database kependudukan dan pengelolaan website desa, serta bimbingan teknis untuk pengolahan dan analisis data profil desa dan pendampingan intensif terkait penyusunan dokumen profil desa, yang selanjutnya telah dapat meningkatkan pengetahuan, keterampilan serta pelayanan publik dari kelompok sasaran

2. 6 (enam) buah peta tematik terkini Desa Dunggala dengan format standar lengkap dengan acuan koordinat lokasi, dilengkapi dengan Buku Perhitungan Peta.

3. database kependudukan berbasis MS Excel yang memuat seluruh data terkait profil desa,

4. 3 buah Buku Profil desa yang terdiri atas Buku 1: Data Dasar Keluarga, Buku 2: Potensi desa dan Buku 3: Tingkat Perkembangan,

5. Buku 4: Monografi Desa dan Buku 5: Desa Dunggala Dalam Angka,

6. Sistem Informasi Desa berbentuk website desa berbasis sistem informasi geografis yang dapat diakses secara daring pada alamat https://dunggala.desa.id, dilengkapi dengan buku panduan penggunaan website desa,

7. HKI untuk jenis ciptaan program komputer "Sistem Informasi Desa Dunggala Kecamatan Tibawa Kabupaten Gorontalo", nomor pencatatan 000149028

8. publikasi dan dokumentasi hasil kegiatan dalam berbagai bentuk (publikasi pada media massa elektronik daring (TV, berita foto, artikel di media masa), dokumentasi video, prototipe website, HKI dan salinan prototipe website desa.

9. Papan informasi digital dengan peraga TV LED berukuran 43 " terpasang di loby Kantor desa

10. Adanya perluasan cakupan layanan internet desa di seluruh lokasi strategis di setiap dusun,

11. Adanya sarana evakuasi bencana, jalur evakuasi dan peta tanggap bencana

12. Adanya 1 (satu) buah buku profil naratif desa Dunggala

13. Terselenggaranya kegiatan tambahan berupa pembuatan infografis desa, pembenahan kantor desa, membantu penyelenggaraan posyandu dan imunisasi balita, kerja bakti, program jumat bersih untuk pembersihan lingkungan sekitar dan 'safari jumat' di setiap mesjid yang ada di desa.

\section{UCAPAN TERIMA KASIH}

Ucapan terima kasih disampaikan kepada Direktorat Riset dan Pengabdian Masyarakat, Direktorat Jenderal Penguatan Riset dan Pengembangan Kementrian Riset, 
Teknologi, dan Pendidikan Tinggi Republik Indonesia, yang telah memberikan alokasi dana untuk pelaksanaan kegitan ini. Terimakasih juga diucapkan kepada Lembaga Penelitian dan Pengabdian Kepada Masyarakat Universitas Negeri Gorontalo, Kepala Desa Dunggala beserta seluruh aparat desa, Karang Taruna, PKK, BPD dan LPM, Kelompok Wanita Tani dan seluruh warga desa Dunggala. Selanjutnya ucapan terima kasih juga disampaikan kepada tim pemetaan Alaska, Japesda Gorontalo dan seluruh tim pengabdian kepada masyarakat yang sudah berkontribusi pikiran dan waktu untuk mensukseskan kegiatan ini.

\section{DAFTAR PUSTAKA}

ANTARAfoto.com. (2019a). Pengembangan Desa Digital Dunggala \#1| ANTARA Foto. Retrieved July 20, 2019, from https://www.antarafoto.com/peristiwa/v15636105 01/pengembangan-desa-digital-dunggala

ANTARAfoto.com. (2019b). Pengembangan Desa Digital Dunggala \#2| ANTARA Foto. Retrieved July 20, 2019, from https://www.antarafoto.com/peristiwa/v15636105 08/pengembangan-desa-digital-dunggala

Badan Informasi dan Geospasial Republik Indonesia. Spesifikasi Teknis Penyajian Peta Desa (2016). Retrieved from https://jdih.big.go.id/hukumjdih/3445764

Bahua, W. (2019). Dunggala Dalam Genggaman YouTube. Retrieved July 27, 2019, from https://www.youtube.com/watch?v=ITL2H6stgj0

BPS Kabupaten Gorontalo. (2018). Kecamatan Tibawa Dalam Angka 2018. Gorontalo. Retrieved from https://gorontalokab.bps.go.id/publication/2018/0 9/26/3d41323ea071a9d602e12b74/kecamatantibawa-dalam-angka-2018.html

Dako, A. Y., \& Ilham, J. (2016). Prototipe Website Untuk Sajian Informasi Profil Desa Binaan Universitas Negeri Gorontalo Sebagai Salah Satu Implementasi Pengembangan Tridharma Perguruan Tinggi. Setrum: Sistem KendaliTenaga-Elektronika-Telekomunikasi-Komputer, 3(2), 77-85. Retrieved from http://jurnal.untirta.ac.id/index.php/jis/article/view 1508

Dako, A. Y., \& Tolago, A. I. (2017). Laporan Pelaksanaan KKN PPM Desa Bongopini Pengelolaan Berkelanjutan Profil Desa Bongopini Dengan Optimasi Dukungan Manajemen Berbasis Komputer. Gorontalo.

Departemen Dalam Negeri Republik Indonesia. (2018). Data Pokok Desa Dunggala. Retrieved from http://prodeskel.binapemdes.kemendagri.go.id/dp okok_grid_t01/

Desa Dunggala. (2019a). KKN Desa DunggalaYouTube. Retrieved from
https://www.youtube.com/watch?v=WqsktHIKOa A

Desa Dunggala. (2019b). Video Profil Singkat Desa Dunggala - YouTube. Retrieved from https://www.youtube.com/watch?v=2im4CwiWY $8 \mathrm{Y}$

dunggala.desa.id. (2019). Mahasiswa KKN PPM di Desa Dunggala. Retrieved August 20, 2019, from https://www.dunggala.desa.id/?page $=$ e827630c6a b5dbad9dda184210f0ddaf\&b80bb7740288fda1f2 $01890375 \mathrm{a} 60 \mathrm{c} 8 \mathrm{f}=2 \& \mathrm{p}=$ view-detail

Ilham, J., \& Dako, A. Y. (2016). Laporan Pelaksanaan KKN PPM Desa Iloheluma - Optimasi Pengelolaan Data Profil Desa Iloheluma Dengan Introduksi Sistem Pengelolaan Berbasis Komputer.

iNews Gorontalo. (2019). Desa Dunggala Dikembangkan Sebagai Desa Digital. Retrieved from

https://www.youtube.com/watch?v=OPzsrWe6TH k\&feature=youtu.be

Kompas TV Gorontalo. (2019, August 20). KOMPAS GORONTALO - Mahasiswa Ciptakan Aplikasi Desa Berbasis Layanan. Kompas TV Gorontalo. Retrieved

from https://www.youtube.com/watch?v=WPzJqraGV YM\&feature $=$ youtu.be\&fbclid=IwAR1IN3GeE_0 nppsw4V6FqZ-knrzu-

9EOAW629Pi7HLUw5skaIlPT-kF3mq0

Pemerintah Desa Dunggala. Rencana Pembangunan Jangka Menengah (RPJMDes) Desa Dunggala (2017). Arsip Desa Dunggala.

Pemerintah Indonesia. Peraturan Menteri Dalam Negeri No. 12 Tahun 2007 Tentang Pedoman Penyusunan dan Pendayagunaan Data Profil Desa dan Kelurahan (2007). Retrieved from http://binapemdes.kemendagri.go.id/produk_huku $\mathrm{m} /$ download/70efdf2ec9b086079795c442636b55f $\mathrm{b}$

Pemerintah Indonesia. Peraturan Menteri Dalam Negeri No. 13 tahun 2012 tentang Monografi Desa dan Kelurahan, Pub. L. No. 13 (2012). Retrieved from http://binapemdes.kemendagri.go.id/produkhuku m/download/14/Permendagri_No._13_Th_._2012 _Ttg_._Monografi_Desa_Dan_Kelurahan_.doc

Pemerintah Indonesia. Undang-Undang No. 6 tahun 2014 tentang desa, Pub. L. No. 6 (2014). Retrieved from http://www.dpr.go.id/dokjdih/document/uu/UU_2 014_6.pdf

Solihin, A. (2019). Desa Dunggala di Gorontalo ciptakan desa digital dibantu mahasiswa KKN ANTARA News. Retrieved August 20, 2019, from https://www.antaranews.com/berita/967438/desadunggala-di-gorontalo-ciptakan-desa-digitaldibantu-mahasiswa-kkn 